\title{
COMMUNITY STRUCTURE AND CONSERVATION OF RARE AND ENDANGERED PLANTS OF GEOMANTIC FOREST IN SOUTHERN CHINA
}

\author{
ZOU, Z. Y. ${ }^{1 \#}-$ HUANG, R. R. ${ }^{2 \#}-$ FAN, Y. M. ${ }^{3}-$ ZHANG, Q. M. ${ }^{4 *}-$ LIU, S. Z. ${ }^{4}-$ CHU, G. W. ${ }^{4}$ \\ ${ }^{1}$ College of Life Sciences, South China Agricultural University, Guangzhou, China \\ ${ }^{2}$ School of Architecture and Civil Engineering, Xiamen University, Xiamen, China \\ ${ }^{3}$ School of Physics and Optoelectronic Engineering, Foshan Institute of Science and \\ Technology, Foshan, China \\ ${ }^{4}$ South China Botanical Garden, Chinese Academy of Sciences, Guangzhou, China \\ ${ }^{\#}$ These authors contributed equally to this work \\ *Corresponding author \\ e-mail:zqm@scib.ac.cn \\ (Received $15^{\text {th }}$ Sep 2019; accepted $15^{\text {th }}$ Nov 2019)
}

\begin{abstract}
Exploring the effects of urbanization on the conservation status of geomantic forest containing rare and endangered plants is very important for the ecological development of southern China. We studied the community structure and habitat characteristics of geomantic forest in Guangzhou City, southern China, as well as the population characteristics of the rare and endangered plant Aquilaria sinensis that resides there. The results showed that, within geomantic forest, there were 23 species vascular plants belonging to 23 genera and 14 families. This community was dominated by tropical and subtropical species. This community was mainly composed with mesophanerophytes, miphanerophytes and mesophyll. The community was less diverse than natural forests in the same region and contained one adult and eight seedling individuals of Aquilaria sinensis. This geomantic forest is a secondary evergreen broad-leaved forest with poor soil. In order to protect rare and endangered plants, as well as native species in this region, we suggest that all geomantic forests with rare and endangered plants in Guangzhou be set as small natural reserves that can be strictly managed. This kind of small natural reserve can facilitate the conservation of regional plant diversity and provide more ecosystem service.
\end{abstract}

Keywords: floristic composition, Shuixi Village, Aquilaria sinensis, soil property, urbanization

\section{Introduction}

Geomantic forest is purposely preserved to maintain the ecological environment in Southern China, Japan, and Korea, and is also shaped by both religion and the traditional culture of geomancy (Kim, 2014, 2017; Fan et al., 2019). The geomantic forest refers to the evergreen broad-leaved forest that has grown on edge of the villages for many years. The geomantic forest not only protects local plant resources but also contains rare and endangered species. In addition to protecting the environment, the geomantic forest also serves as a gene bank for the development and utilization of biological resources in the future (Cheng, 2011; Ye et al., 2013). Monsoon evergreen broad-leaved forests, with their complex community structure and rich biodiversity, are the typical zonal vegetation in southern China. They are an important part of the subtropical terrestrial ecosystem and play an important role in ecosystem services (Ren et al., 1996; Song et al., 2005). The monsoon evergreen broad-leaved forests in Southern China are mainly preserved in the form of nature reserves. Most of the geomantic forests in Guangzhou are inhabited by the 
rare, endangered Aquilaria sinensis plant, but the forests are scattered and have been seriously damaged by deforestation and related human activities (Ye et al., 2013).

Aquilaria sinensis is a perennial tropical and subtropical evergreen tree that belongs to the Thymelaeaceae family. It is listed as a national second-class protected plant and an internationally protected tree. Aquilaria sinensis is a valuable resource in Chinese herbal medicine and is listed as one of the top ten broad-spectrum drugs (Mao et al., 2017; Wang et al., 2012). Due to over-harvesting, few Aquilaria sinensis individuals remain in the wild.

As a typical Chinese traditional forest, geomantic forest has mainly been studied in China, where research has been conducted to analyze their classification and conservation value (Hu et al., 2011; Luo et al., 2011; Tang et al., 2012; Deng, 2013; Gao et al., 2013), species composition and diversity (Liu et al., 2005; Mo et al., 2011; Lee et al., 2017; Lü et al., 2009c), community structure characteristics (Cai et al., 1998; Yang et al., 2012; Kong et al., 2013; Chen, 2017; Zhu et al., 2011; Lü et al., 2009a, b), biomass and carbon storage (Lu, 2017), spatial form and distribution (Lin et al., 2013), plant resources and utilization (Li et al., 2013), landscape reconstruction and planning, related human settlements and environmental culture (Cheng, 2011; Ye et al., 2013). The community characteristics and protection of Aquilaria sinensis in Guangzhou were also analyzed by several scholars (Zhu et al., 2011). In general, however, there are few studies on rare and endangered plants and their habitats in geomantic forest. The geomantic forest, home to many local native species, endemic species, and rare and endangered plants, is a local source of species diversity and provides shelter for rare and endangered plants (Ye et al., 2013). Within the Luogang District in Guangzhou City there are 15 geomantic forests, all with similar species composition and community structure (Ye et al., 2013).

For this analysis, we focused our research on the geomantic forest in Shuixi Village, which is representative of the geomantic forest in Guangzhou and is inhabited by Aquilaria sinensis. Shuixi Village is located in the eastern suburbs of Guangzhou. After relocation to the Huangpu District in 2014, it has become an important area for development and transformation. Shuixi Village was listed as one of the old village reconstruction projects in Guangzhou in 2016. With the growing population and increased economic development of the village, the forest faces the negative effects of human interference and climate change caused by urbanization. In this study, we examined the community structure of the geomantic forest in Shuixi Village, as well as the structure and community habitat of the Aquilaria sinensis population within this forest. Specifically, we addressed the following three topics: (1) the community structure and habitat of the geomantic forest, (2) the population status of Aquilaria sinensis in the geomantic forest and (3) the strategies to protect the geomantic forest, as well as its rare and endangered plants.

\section{Materials and methods}

\section{Research site}

The geomantic forest (Fig. 1), with an area of approximately 6 hectares, is located at the rear of Shuixi Village, in northeast Guangzhou, Guangdong Province, China, $113^{\circ} 28^{\prime} 41.6^{\prime \prime} \mathrm{N}, 23^{\circ} 11^{\prime} 49.2^{\prime \prime} \mathrm{E}$. The forest is located about $50 \mathrm{~m}$ above sea level, and has an eastern slope of $15^{\circ}$. It belongs to the lower subtropical monsoon climate, and has an average annual temperature of $23{ }^{\circ} \mathrm{C}$. The lowest temperature occurs in January and is $13{ }^{\circ} \mathrm{C}$, and the highest temperature is $28^{\circ} \mathrm{C}$ and occurs in August (Mao et al., 2017). The annual average humidity is about $79 \%$, the annual average rainfall is about $1700 \mathrm{~mm}$, and the rainy season is from April to October (Zhu et al., 2011; Yi et al., 2012). The zonal 
vegetation in this area is the lower subtropical monsoon evergreen broad-leaved forest, and the zonal soil is laterite. Shuixi Village covers a significant area with a large population. It is surrounded by artificially planted Acacia mangium, Cinnamomum burmanni, and Manglietia glauca. In the geomantic forest, Acacia mangium covers the most area, and native species only cover about $900 \mathrm{~m}^{2}$. There are some signs of deforestation and we find that human activities have affected the geomantic forest, as there are traces of raising chickens, stacking garbage and walking around the forest.

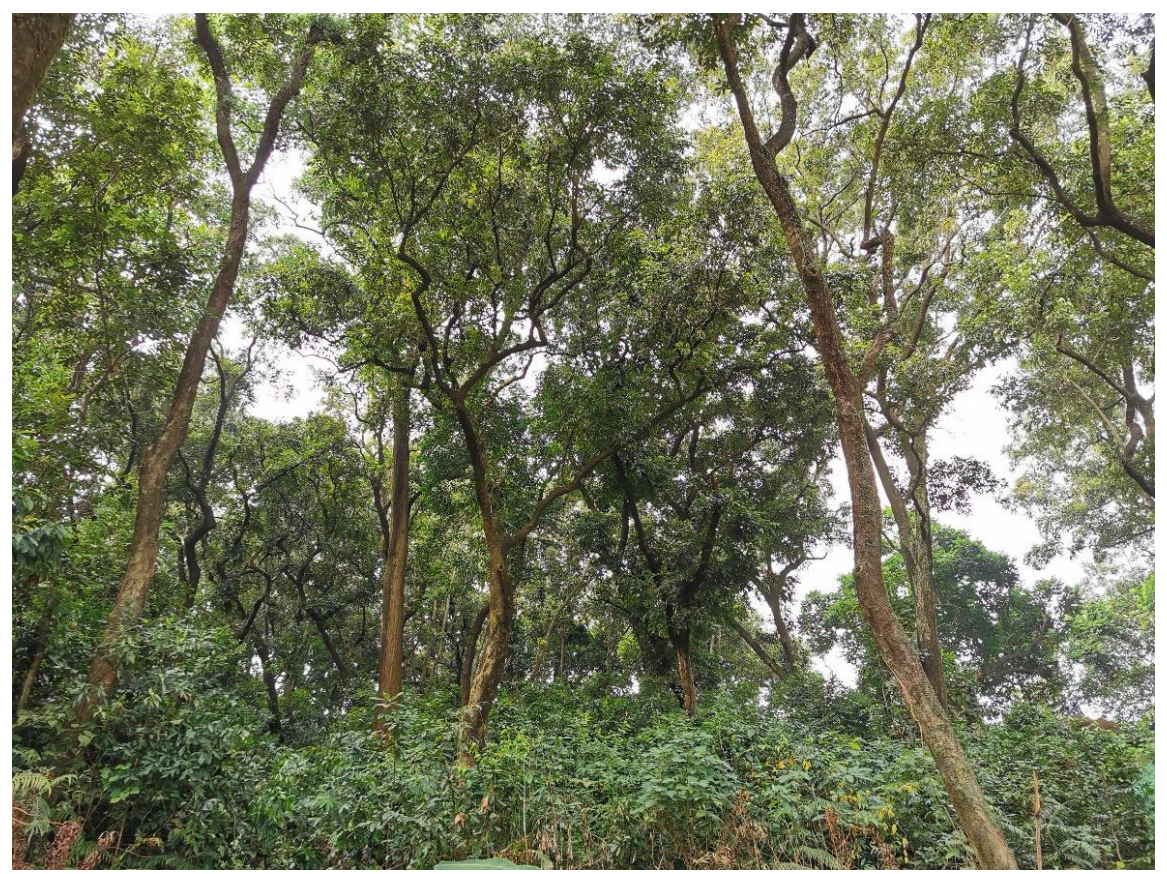

Figure 1. The community structure and habitat of the geomantic forest

\section{Investigation and analysis methods}

The typical community sampling method was used to investigate the vegetation of the geomantic forest in Shuixi Village in November 2017. Samples of soil and leaf litter were also taken for analysis. As mentioned above, the area of the geomantic forest where native species remain is about $900 \mathrm{~m}^{2}$. Only eight $10 \mathrm{~m} \times 10 \mathrm{~m}$ quadrates were established in the area containing native species. We investigated the crown density, species, plant height, and diameter at breast height (DBH) in the arbor layer, where the $\mathrm{DBH}$ is $\geq 1 \mathrm{~cm}$. A $5 \mathrm{~m} \times 5 \mathrm{~m}$ shrub quadrate was randomly selected from each $10 \mathrm{~m} \times 10 \mathrm{~m}$ quadrate, and a $1 \mathrm{~m} \times 1 \mathrm{~m}$ herb layer was randomly set in the shrub quadrate (Ren et al., 1996). The species name, height, and coverage of each individual in the shrub and herb quadrates were recorded. Three $1 \mathrm{~m} \times 1 \mathrm{~m}$ litter layers were randomly collected from each $10 \mathrm{~m} \times$ $10 \mathrm{~m}$ square to measure the litter standing crop in the ground layer (Ren et al., 1998).

Five $10 \mathrm{~m} \times 10 \mathrm{~m}$ quadrates were selected for soil property analysis. In each of the five quadrates chosen, six soil samples $(0-20 \mathrm{~cm})$ were randomly collected using drilling tools and mixed. Soil samples were brought back to the laboratory. Samples were air-dried and sieved for analysis of soil organic matter, $\mathrm{pH}, \mathrm{N}, \mathrm{P}$, and $\mathrm{K}$ contents. The analysis method followed Peng (1996) and Ren et al. (1996). There were five replicates per site (i.e. one replicate per quadrat). In addition, the leaf area index and extinction coefficient were analyzed using the LAI-2000 plant canopy analyzer (Ren et al., 1996). 


\section{Data analysis}

Based on the standards of Raunkiaer's Life-form Spectrum and the Flora of China and Guangdong Flora (Cai et al., 1998), various life forms of plants were comprehensively determined. Field observations and survey data were used to determine the leaf type. The basal area, frequency, relative frequency, relative density, relative significance, importance value, diversity index, ecological dominance and uniformity index were calculated (Ren et al., 1996). The species composition of the shrub layer in the community, the spatial structure, the species structure of Aquilaria sinensis and the soil chemical properties were determined. The relevant equations are as follows:

$$
\begin{aligned}
& \begin{array}{l}
\text { Important value } I V \\
=
\end{array} \\
& \text { Shannon-Wiener index } H P=-\sum(P i \times \ln P i)=-\sum|(N i / N) \times \ln (N i / N)| \text { (Eq.2) } \\
& \text { Ecological dominance } C=N i(N i-1) /[N(N-1)] \\
& \text { Pielou evenness index } J S W=-\sum(P i \ln P i) / \ln S
\end{aligned}
$$

where $P i$ is the relative abundance of the $i$-th species, $N i$ is the number of plants of the $i$ th species, $N$ is the total number of plants, and $S$ is the total number of species (Peng, 1996; Luo et al., 2011).

The data were processed using Office Excel.

\section{Results and analysis}

\section{Community structure}

Geomantic forests are evergreen all year round, with an overall height of about $10 \mathrm{~m}$ and a canopy closure of about $70 \%$. The leaf area index (LAI) of the community is 4.98 and the extinction coefficient, $\mathrm{K}$, is 0.325 . The canopy layer is discontinuous, and there is a notable vertical stratification of tree layer, shrub layer and herb layer.

In the $800 \mathrm{~m}^{2}$ area, there are 167 individuals, some of which are monoecious, bringing the total to 178 individuals in the arbor layer. These individuals belong to 14 families and 23 genera, and have an average DBH of $6.8 \mathrm{~cm}$ and an average height of $5.5 \mathrm{~m}$. Among 178 individuals, there are three genera and three species in each family of Euphorbiaceae, Rubiaceae and Polygonaceae. The arbor layer is dominated by families and genera of tropical and subtropical plants. There are 115 individuals shorter than $5 \mathrm{~m}$, making up $65 \%$ of the total; 43 individuals between $5-10 \mathrm{~m}$ tall, accounting for $24 \%$ of the total and 20 individuals taller than $10 \mathrm{~m}$ occupying $11 \%$ of the total. There are 124 individuals with a DBH within $5 \mathrm{~cm}$, accounting for $70 \%$ of the total, 33 individuals with a DBH between 5 and $10 \mathrm{~cm}$, making up $18 \%$ of the total, and 21 individuals with a DBH greater than $10 \mathrm{~cm}$, occupying $12 \%$ of the total. In general, the community is relatively short, with the majority of trees being small in size.

The geomantic forest community is made up of a diverse array of species. In the arbor layer, four species, including Engelhardia roxburghiana Wall., Acacia mangium Willd., Psychotria rubra (Lour.) Poir., and Aporosa dioica (Roxb.) Muell. Arg., account 
for about $65 \%$ of the importance value (Table 1). There are only seven large Acacia mangium individuals, which have the largest height and DBH within the community. This species has no young individuals. As the pioneer species, it will gradually withdraw from the community. Astragalus membranaceus, which is the most dominant species in the arbor layer, has 31 individuals. Psychotria rubra and Aporosa dioica have the largest number of individuals, all of which are short, small trees. There are 13 species of shrubs, 10 of which are also present in the arbor layer, and one of which is also present in the herb layer (Table 2). There are seven species within the herbaceous layer, four of which also in the arbor layer, one of which is present in the shrub layer, and two of which are ferns (Tables 1-3).

According to the Raunkiaer's Life-form Spectrum, among the 23 species in the arbor layer, only five species are middle phanerophytes, and the other 18 species are small phanerophytes. Moreover, two species have large-sized leaves and five species have small-sized leaves. The other 16 species have medium-sized leaves. In the wild, plants in this community predominantly have leathery, single medium-sized leaves. The Shannon-Wiener biodiversity index of the arbor layer is 2.458 , which is significantly lower than the diversity index of 4.01 in the Dinghu Mountain zonal vegetationmonsoon evergreen broad leaved forest in 1992. The indexes of ecological dominance and uniformity have little difference, as they are 0.13 and 0.784 , respectively (Ren et al., 1996).

\section{Population structure of the rare species Aquilaria sinensis}

There is one Aquilaria sinensis individual in the arbor layer, with a DBH of $8 \mathrm{~cm}$ and a height of $6.5 \mathrm{~m}$ in the geomantic forest. There are six Aquilaria sinensis individuals in the shrub layer, one with a basal diameter of $1.3 \mathrm{~cm}$ and a height of $1.7 \mathrm{~m}$, four with a basal diameter of $0.7 \mathrm{~cm}$ and a height of $0.7 \mathrm{~m}$, and one with a basal diameter of $0.4 \mathrm{~cm}$ and a height of $0.6 \mathrm{~m}$. Two Aquilaria sinensis individuals occupy the herbaceous layer, with a height of $0.2 \mathrm{~m}$. The importance value of Aquilaria sinensis is 0.72 , accounting for $0.7 \%$ of the community. Aquilaria sinensis is a mesophanerophyte, a group which makes up a small portion of the community. Aquilaria sinensis is also a species with medium-sized leaves, and these types of species occupy a large portion of the community.

\section{Soil properties of the community}

The soil in the sample plot consists of a thick layer of fertile laterite. The average weight of the litter layer is $530 \pm 50.99 \mathrm{~g} \mathrm{~m}^{-2}$, and the litter layer is rich in humus. The A layer of soil, with a thickness of $0-20 \mathrm{~cm}$, has a $\mathrm{pH}$ of 4.46 , making it acidic. The organic content is $30.48 \mathrm{~g} \mathrm{~kg}^{-1}$, and the total nitrogen content is $1.18 \mathrm{~g} \mathrm{~kg}^{-1}$. The main chemical properties of the soils are shown in Table 4. The soil of this community is similar to that of nearby Changlong Village in Longgang District and Zhongling Village in Zengcheng District, but there are some differences. Overall, the soil fertility of the sample plot is not as high as that of the zonal climax vegetation in Dinghu Mountain. This indicates that the soil fertility of the small-size geomantic forest has been influenced by human activities and needs to be improved to be on par with that of the natural soil in a large-size nature reserve. The content of organic matter and available potassium in this plot is particularly high, which may be related to activities of local villagers, such as raising chickens and stacking garbage. 
Table 1. Species and its important value in arbor layer

\begin{tabular}{|c|c|c|c|c|c|c|c|c|}
\hline No. & Species & Families & Genera & Lifestyle & $\begin{array}{l}\text { Number } \\
\text { of trees }\end{array}$ & $\begin{array}{l}\text { Average } \\
\mathrm{DBH} / \mathrm{cm}\end{array}$ & $\begin{array}{c}\text { Average } \\
\mathrm{H} / \mathrm{m}\end{array}$ & $\begin{array}{c}\text { Importance } \\
\text { values }\end{array}$ \\
\hline 1 & $\begin{array}{l}\text { Engelhardia } \\
\text { roxburghiana Wall. }\end{array}$ & Juglandaceae & Engelhardia & Mesophanerophyte & 31 & 15.5 & 9.6 & 26.54 \\
\hline 2 & Acacia mangium Willd. & Fabaceae & Acacia & Mesophanerophyte & 7 & 41.5 & 21.0 & 16.78 \\
\hline 3 & $\begin{array}{l}\text { Psychotria rubra } \\
\text { (Lour.) Poir. }\end{array}$ & Psychotria & Psychotria & Microphanerophyte & 45 & 2.5 & 2.8 & 12.04 \\
\hline 4 & $\begin{array}{c}\text { Aporusa dioica (Roxb.) } \\
\text { Müll. Arg. }\end{array}$ & Euphorbiaceae & Aporusa & Microphanerophyte & 26 & 3.6 & 3.8 & 9.10 \\
\hline 5 & $\begin{array}{c}\text { Endospermum chinense } \\
\text { Benth }\end{array}$ & Euphorbiaceae & Endospermum & Mesophanerophyte & 9 & 8.1 & 9.0 & 4.94 \\
\hline 6 & $\begin{array}{c}\text { Castanopsis chinensis } \\
\text { Hance }\end{array}$ & Fagaceae & Castanopsis & Mesophanerophyte & 8 & 4.9 & 5.0 & 4.09 \\
\hline 7 & $\begin{array}{l}\text { Garcinia multiflora } \\
\text { Champ. Ex Benth. }\end{array}$ & Clusiaceae & Garcinia & Microphanerophyte & 8 & 2.8 & 3.6 & 3.91 \\
\hline 8 & \begin{tabular}{|c|} 
Litsea \\
rotundifoliaHemsl. Var. \\
oblongifolia (Nees) \\
Allen
\end{tabular} & Lauraceae & Litsea & Microphanerophyte & 7 & 1.9 & 3.0 & 3.19 \\
\hline 9 & $\begin{array}{c}\text { Acronychia } \\
\text { pedunculata (L.) Miq. }\end{array}$ & Rutaceae & Acronychia & Microphanerophyte & 6 & 5.2 & 5.8 & 3.19 \\
\hline 10 & $\begin{array}{c}\text { Ardisia quinquegona } \\
\text { B1. }\end{array}$ & Myrsinaceae & Ardisia & Microphanerophyte & 7 & 1.5 & 2.9 & 3.18 \\
\hline 11 & $\begin{array}{c}\text { Ilex asprella (Hook. et } \\
\text { Arn.) Champ. ex } \\
\text { Benth. }\end{array}$ & Aquifoliaceae & Ilex & Microphanerophyte & 4 & 1.4 & 2.4 & 2.15 \\
\hline 12 & $\begin{array}{c}\text { Cinnamomum } \\
\text { burmanni (Nees et T. } \\
\text { Nees) Blume }\end{array}$ & Lauraceae & Cinnamomum & Microphanerophyte & 3 & 1.5 & 2.8 & 1.50 \\
\hline 13 & $\begin{array}{c}\text { Glochidion eriocarpum } \\
\text { Champ. ex Benth. }\end{array}$ & Euphorbiaceae & Glochidion & Microphanerophyte & 3 & 1.4 & 2.6 & 1.50 \\
\hline 14 & $\begin{array}{l}\text { Archidendron lucidum } \\
\text { Benth. }\end{array}$ & Fabaceae & Archidendron & Microphanerophyte & 2 & 1.2 & 2.4 & 1.30 \\
\hline 15 & $\begin{array}{l}\text { Manglietie glauca } \\
\text { Blume }\end{array}$ & Magnoliaceae & Manglietie & Microphanerophyte & 2 & 4.1 & 5.1 & 0.88 \\
\hline 16 & $\begin{array}{l}\text { Aidia pycnantha } \\
\text { (Drake) Tirveng. }\end{array}$ & Psychotria & Aidia & Microphanerophyte & 2 & 3.4 & 4.1 & 0.86 \\
\hline 17 & $\begin{array}{l}\text { Schefflera octophylla } \\
\text { (Lour.) Harms }\end{array}$ & Araliaceae & Schefflera & Mesophanerophyte & 2 & 1.3 & 2.2 & 0.84 \\
\hline 18 & $\begin{array}{l}\text { Aquilaria sinensis } \\
\text { (Lour.) Spreng. }\end{array}$ & Thymelaeaceae & Aquilaria & Mesophanerophyte & 1 & 8.0 & 6.5 & 0.72 \\
\hline 19 & \begin{tabular}{|c|} 
Cratoxylum \\
cochinchinense (Lour.) \\
Bl.
\end{tabular} & Clusiaceae & Cratoxylum & Microphanerophyte & 1 & 4.3 & 4.5 & 0.67 \\
\hline 20 & $\begin{array}{c}\text { Adina pilulifera (Lam.) } \\
\text { Franch. ex Drake }\end{array}$ & Psychotria & Adina & Microphanerophyte & 1 & 2.2 & 3.5 & 0.66 \\
\hline 21 & $\begin{array}{l}\text { Viburnum sempervrens } \\
\text { K. Koch }\end{array}$ & Caprifoliaceae & Viburnum & Microphanerophyte & 1 & 1.4 & 2.2 & 0.65 \\
\hline 22 & $\begin{array}{c}\text { Machilus chekiangensis } \\
\text { S. Lee }\end{array}$ & Lauraceae & Machilus & Mesophanerophyte & 1 & 1.3 & 2.7 & 0.65 \\
\hline \multirow[t]{2}{*}{23} & $\begin{array}{c}\text { Melicope pteleifolia } \\
\text { (Champ. ex Benth.) T. } \\
\text { Hartley }\end{array}$ & Rutaceae & Melicope & Microphanerophyte & 1 & 1.0 & 2.2 & 0.65 \\
\hline & Total & & & & 178 & 6.8 & 5.5 & 100 \\
\hline
\end{tabular}


Table 2. Species composition in shrub layer

\begin{tabular}{|c|c|c|c|c|c|c|c|}
\hline No. & Species & Families & Genera & Lifestyle & $\begin{array}{c}\text { Number } \\
\text { of trees }\end{array}$ & \begin{tabular}{|c|} 
Average \\
$\mathrm{H} / \mathrm{cm}$
\end{tabular} & $\begin{array}{l}\text { Average base } \\
\text { diameter } / \mathrm{cm}\end{array}$ \\
\hline 1 & $\begin{array}{c}\text { Litsea rotundifoliaHemsl. Var. } \\
\text { oblongifolia (Nees) Allen }\end{array}$ & Lauraceae & Litsea & Microphanerophyte & 5 & 93.3 & 0.6 \\
\hline 2 & $\begin{array}{l}\text { Garcinia multiflora Champ. Ex } \\
\text { Benth. }\end{array}$ & Clusiaceae & Garcinia & Microphanerophyte & 2 & 80.0 & 0.9 \\
\hline 3 & $\begin{array}{c}\text { Alchornea trewioides (Benth.) } \\
\text { Muell. Arg. }\end{array}$ & Euphorbiaceae & Alchornea & Nanophanerophytes & 2 & 100.0 & 0.5 \\
\hline 4 & $\begin{array}{c}\text { Acronychia pedunculata (L.) } \\
\text { Miq. }\end{array}$ & Rutaceae & Acronychia & Microphanerophyte & 3 & 80.0 & 0.6 \\
\hline 5 & Psychotria rubra (Lour.) Poir. & Psychotria & Psychotria & Microphanerophyte & 20 & 93.3 & 0.9 \\
\hline 6 & Archidendron lucidum Benth. & Fabaceae & Archidendron & Microphanerophyte & 1 & 100.0 & 0.5 \\
\hline 7 & Ixora chinensis Lam. & Psychotria & Ixora & Nanophanerophytes & 2 & 60.0 & 0.4 \\
\hline 8 & Ardisia quinquegona $\mathrm{B} 1$. & Araliaceae & Ardisia & Microphanerophyte & 6 & 140.0 & 1.1 \\
\hline 9 & $\begin{array}{l}\text { Glochidion eriocarpum Champ. } \\
\text { Ex Benth. }\end{array}$ & Euphorbiaceae & Glochidion & Microphanerophyte & 4 & 95.0 & 0.8 \\
\hline 10 & $\begin{array}{l}\text { Aquilaria sinensis (Lour.) } \\
\text { Spreng. }\end{array}$ & Thymelaeaceae & Aquilaria & Mesophanerophyte & 6 & 100.0 & 0.8 \\
\hline 11 & Gardenia jasminoides Ellis & Psychotria & Gardenia & Nanophanerophytes & 1 & 21 & 0.7 \\
\hline 12 & $\begin{array}{c}\text { Cinnamomum burmanni (Nees } \\
\text { et T. Nees) Blume }\end{array}$ & Lauraceae & Cinnamomum & Microphanerophyte & 1 & 120.0 & 1.0 \\
\hline \multirow[t]{2}{*}{13} & $\begin{array}{c}\text { Aporusa dioica (Roxb.) Müll. } \\
\text { Arg. }\end{array}$ & Euphorbiaceae & Aporusa & Microphanerophyte & 10 & 103.3 & 0.9 \\
\hline & Total & & & & 63 & 91.2 & 0.8 \\
\hline
\end{tabular}

Table 3. Species composition in grass layer

\begin{tabular}{c|c|c|c|c|c|c|c}
\hline No. & Species & Families & Genera & Lifestyle* & $\begin{array}{c}\text { No. of } \\
\text { trees }\end{array}$ & $\begin{array}{c}\text { Average } \\
\text { H/cm }\end{array}$ & $\begin{array}{c}\text { Coverage } \\
/ \%\end{array}$ \\
\hline 1 & Pteris semipinnata Linn & Pteridaceae & Pteris & Fern & 5 & 45.0 & 6.0 \\
\hline 2 & $\begin{array}{c}\text { Litsea rotundifoliaHemsl. Var. } \\
\text { oblongifolia (Nees) Allen }\end{array}$ & Lauraceae & Litsea & Microphanerophyte & 3 & 10.0 & 1.0 \\
\hline 3 & Psychotria rubra (Lour.) Poir. & Psychotria & Psychotria & Microphanerophyte & 4 & 17.5 & 3.5 \\
\hline 4 & Ixora chinensis Lam. & Psychotria & Ixora & Nanophanerophytes & 3 & 25.0 & 2.0 \\
\hline 5 & Ardisia quinquegona Bl. & Myrsinaceae & Ardisia & Microphanerophyte & 2 & 35.0 & 4.0 \\
\hline 6 & Adiantum flabellulatum Linn. & Adiantaceae & Adiantum & Fern & 4 & 15.0 & 3.0 \\
\hline 7 & Aquilaria sinensis (Lour.) Spreng. & Thymelaeaceae & Aquilaria & Mesophanerophyte & 2 & 20.0 & 4.0 \\
\hline & Total & & & & $\mathbf{2 3}$ & $\mathbf{2 4 . 5}$ & $\mathbf{2 3 . 5}$ \\
\hline
\end{tabular}

Table 4. Chemical properties of the soils

\begin{tabular}{c|c|c|c|c|c|c|c}
\hline Location & pH value & $\begin{array}{c}\text { Organic matter } \\
/(\mathbf{g} * \mathbf{k g - 1})\end{array}$ & $\begin{array}{c}\text { Total N } \\
/(\mathbf{g} * \mathbf{k g - 1})\end{array}$ & $\begin{array}{c}\text { Total P } \\
/(\mathbf{g} \text { (kg-1) }\end{array}$ & $\begin{array}{c}\text { Effective P } \\
/ \mathbf{p p m}\end{array}$ & $\begin{array}{c}\text { Total K } \\
/ \%\end{array}$ & $\begin{array}{c}\text { Available K } \\
/ \mathbf{p p m}\end{array}$ \\
\hline Shuixi Village * & $4.46 \pm 0.06$ & $30.48 \pm 2.38$ & $1.18 \pm 0.06$ & $0.252 \pm 0.03$ & $3.95 \pm 2.67$ & $3.19 \pm 0.15$ & $52.32 \pm 12.09$ \\
\hline Zhongling Village** & 4.42 & 15.06 & 0.70 & 0.15 & 1.53 & 1.41 & 20.11 \\
\hline Changlong Village 1** & 3.84 & 14.70 & 8.20 & 0.31 & & 1.80 & \\
\hline Changlong Village 2** & 3.76 & 37.60 & 1.97 & & & & \\
\hline Mount Dinghu** & 4.10 & 24.80 & 2.00 & 0.80 & 4.60 & 3.70 & 14.20 \\
\hline
\end{tabular}

*The data measured in Shuixi Village include standard deviation. **The data measured in Zhongling Village are from our investigation. The data measured in Changlong Village 1 are cited from Zhu Baozhu (2011). The data measured in Changlong Village 2 are cited from Cai Xi'an (1998). The data measured in Mount Dinghu are cited from Peng Shaolin (1996) 


\section{Discussion}

The community structure indicates that the geomantic forest is a secondary monsoon evergreen broad-leaved forest. There are artificially planted Acacia mangium individuals outside the native species community. The community species are somewhat similar to those seen in the monsoon evergreen broad-leaved forest at Dinghu Mountain, despite the presence of Acacia mangium. However, the geomantic forest in Shuixi Village also shows tropical and subtropical properties in its floristic composition, community life type and leaf type spectrum. However, there are no plate-like roots, cladanthy, drip-tip plants, or woody vines that are typically observed in natural vegetation. Compared with natural forests, the number of species in the geomantic forest in Shuixi Village is smaller, the population density is lower, the overall height of the vegetation is shorter and the DBH of the vegetation is smaller. There are only three layers in this community, arbor, shrub and herb, meaning that the liana layer, three sublayers of the arbor and five sub-layers of shrub and herb that are present in natural forests are missing in the Shuixi village forest. Although the community is mainly composed of species with medium-sized leaves, it is different from the structure of natural forests, which have reasonable proportions of species with various types of leaves. The mesophanerophytes and miphanerophytes are the main components of the community, and there are no phaenerophytes. This is mainly due to the fact that the community is not mature enough. In addition, the community's diversity index is significantly lower than that of Dinghu Mountain (Ren et al., 1996). Therefore, this geomantic forest is a lower subtropical monsoon evergreen broad-leaved forest displaying secondary growth after human disturbances. However, the species coefficient of this forest is $100 \%$, indicating that it still has a large development trend with its species richness (Cai et al., 1998).

In terms of the soil chemical properties, the fertile lateritic soil of this geomantic forest is the same as that of the monsoon evergreen broad-leaved forest in Dinghu Mountain. However, aside from the organic matter and available potassium levels, other indicators of the soil health in the geomantic forest are lower than those for the soil in the Dinghu Mountain forest. Moreover, soil indicators in the geomantic forest in Shuixi Village are also different from those of the other nearby geomantic forests (Fan et al., 2019). There are two possible reasons for the increased soil fertility in this geomantic forest. First, the geomantic forest is close to the village where there are chickens and garbage, which may contaminate the soil. Second, the vegetation is inferior to what is observed in natural forests, which is the result of various types of disturbances. Despite this, the geomantic forest in Shuixi Village still has high soil fertility and can ensure the growth of the native vegetation.

There are nine Aquilaria sinensis individuals in the geomantic forest in Shuixi Village. These individuals have a certain age structure, indicating that they are still capable of self-renewal, and the habitat of this community is suitable for the regeneration and growth of Aquilaria sinensis. In particular, the acidic soil ( $\mathrm{pH} 4.46)$ of the geomantic forest in Shuixi Village makes it suitable for Aquilaria sinensis growth. The nutrient content of the soil in the Shuixi Village geomantic forest is generally lower than that of the forest in Dinghu Mountain, however, Aquilaria sinensis can adapt to nutrient-poor environments (Wang et al., 2012). The poor soil affects the secretion of the resin from Aquilaria sinensis, and in terms of resin quality, growth in barren soil may be better than growth in fertile soil (Luo et al., 2011). 
With the rapid development of society and the acceleration of urbanization in Southern China, the disturbance of the monsoon evergreen broad-leaved forest in Shuixi Village is becoming more serious. Both the distribution and area of the forest are shrinking. Meanwhile, the forest quality is decreasing, leading to a simplified community structure, decreased function, invasion of exotic species, and the disappearance of a large number of rare species. In this area, the ability of the forest to positively influence climate regulation and water conservation will be weakened to some extent, and the soil will be degraded. The geomantic forest in Shuixi Village is a natural secondary forest but it is also part of the urban landscape. The geomantic forest is well-preserved compared to other types of forests, but it also reveals the influence of urbanization and human disturbance on natural forest (Chen et al., 2018). This forest is a local species bank and the provenance of rare and endangered plants in the region. It is also part of a unique environmental and cultural tradition in Southern China, making it an important resource for studying zonal forest communities, local culture and history. Furthermore, the forest provides certain ecological services, as well as landscape cultural value. Overall, the geomantic forest is an important element in the construction of rural landscapes and it needs to be actively preserved (Lin et al., 2013).

\section{Conclusion}

Shuixi Village in Guangzhou is representative of the other villages located in the center of the Guangdong-Hong Kong-Macao Greater Bay Area and its geomantic forest is characteristic of those seen in urban cities. The geomantic forest in the region can help preserve and recover the monsoon evergreen broad-leafed forest in the region, and maintain the harmony between humans and nature, thus promoting sustainable ecological development in the Greater Bay Area. The nature reserves were effectively protected by regulations and laws. However, there are no such regulations or laws in place to protect geomantic forests. Therefore, setting environmental regulations for geomantic forests, where most rare and endangered plants grow, will provide ecological support for sustainable development and will improve the ecological civilization in the Greater Bay Area. In addition, the dynamic monitoring and ecosystem service on geomantic forest is needed in future.

Acknowledgements. This work is supported by Guangdong Forestry Ecology Positioning Monitoring Network Platform Construction Project (2019KJCX021); Dinghushan Forest Ecosystem Research Station, the Chinese Academy of Sciences; and Dinghushan Forest Ecosystem National Field Scientific Observation and Research Station, the Ministry of Science and Technology, China.

\section{REFERENCES}

[1] Cai, X. A., Peng, S. L., Cao, H. L., Yu, Z. Y. (1998): Community analysis of a secondary evergreen broadleaved forest at Luogang, Guangzhou, China. - Journal of Applied and Environmental Biology 4(2): 107-114.

[2] Chen, B. X., Chris, C., Jesse, M., Zhang, Y. (2018): Fengshui forests and village landscapes in China: Geographic extent, socioecological significance, and conservation prospects. - Urban Forestry \& Urban Greening 31: 79-92.

[3] Chen, W. F. (2017): Study on community structure of Fengshui Forest in Dongguan. Agriculture and the Ecological Environment 26: 101-103. 
[4] Cheng, J. (2011): Survey and Research of Village Geomantic Wood in Pearl River Delta. - Beijing Forestry University, Beijing.

[5] Deng, J. (2013): Discussion on the ecological characteristics and conservation value of Fengshui Forest. - Journal of Heilongjiang Vocational Institute of Ecological Engineering 26(5): 9-10.

[6] Fan, Y. M., Zhang, Q. M., Zou, Z. Y., Liu, S. Z., Chu, G. W. (2019): The community structure and its rare and endangered plants conservation status of geomantic forest at Zhongling village in Guangzhou. - Ecological Science 38(2): 162-167.

[7] Gao, H., Ouyang, Z., Chen, S. (2013): Role of culturally protected forests in biodiversity conservation in Southeast China. - Biodiversity and Conservation 22: 531-544.

[8] Hu, L., Li, Z., Liao, W. B., Fan, Q. (2011): Values of village Fengshui Forest patches in biodiversity conservation in the Pearl River Delta, China. - Biological Conservation 144: 1553-1559.

[9] Kim, Y. S. (2014): A study on Kimon evasion in Japanese Fengshui. - Journal of East Aisan Cultures 56: 161-187.

[10] Kim, Y. S. (2017): A theoretical review on the planting and management of coastal forests in Korea. - Korean Journal of Plant Resources 30: 110-123.

[11] Kong, B., Cao, H. L., Ma, L., Wu, L. F., Chen, C., L, H. Z. (2013): Community characteristics of the Fengshui-wood of Erythrophleum fordii in Guangzhou. - Tropical Geography 33(3): 307-313.

[12] Lee, E., Krasny, M. E. (2017): Adaptive capacity in community forest management: a systematic review of studies in East Asia. - Environmental Management 59: 34-49.

[13] Li, S. Y., Ye, Y. S., Wang, F. G., Zeng, F. Y., Xu, Z. C. (2013): Analyses on species composition and areal-type of "Fengshui woods" in Guangzhou City. - Journal of Plant Resources and Environment 22(1): 102-109.

[14] Lin, G. J., Ma, L., Wu, L. F., Huang, M. C., Cao, H. L., Ye, H. G. (2013): Community heterogeneity of Fengshui Woods in Guangzhou and its contribution to regional species diversity. - Journal of Tropical and Subtropical Botany 21(2): 168-174.

[15] Liu, S. S., Ye, Y. C., Zhang, Z. S., Li, N. S., Zhu, J. Y., Cao, H. L. (2005): The species composition of secondary forest at Dalinshan in Dongguan City and its contribution to the species pool. - Guangdong Forestry Technology 21(4): 18-22.

[16] Lü, H. R., Liu, S. S., Ye, Y. C., Zhu, J. Y., Mo, L. J., Chen, H. Y. (2009a): The characteristics of Fungshui woods Pygeum to Pengii Endospermum chinense community in Fenggang Town, Dongguan City. - Journal of Tropical and Subtropical Botany 17(2): 613-619.

[17] Lü, H. R., Liu, S. S., Ye, Y. C., Zhu, J. Y., Mo, L. J., Chen, H. Y. (2009b): Impacts of anthropogenic disturbance on tree species composition and diversity of Fungshui Forest community in Dongguan City of Guandong Province. - Chinese Journal of Ecology 28(4): 613-619.

[18] Lü, H. R., Liu, S. S., Zhu, J. Y., Ye, Y. C., Chen, H. Y., Mo, L. J. (2009c): Effects of human disturbance on understory woody species composition and diversity in Fengshui Forests. - Biodiversity Science 17(5): 458-467.

[19] Lu, Z. B. (2017): Distribution of Fengshui Forest biomass and carbon reserves in Dongguan Forest by product and speciality in China. - Forest by Product and Speciality in China 150(5): 43-45.

[20] Luo, S. Q., Tang, G. D., Zheng, M. X., Qiu, J. L., Ma, H. Y., Hou, B. Q., Xu, Z. C. (2011): Classification and conservation strategy of geomantic forests in Conghua Municipality, Guangdong Province. - Journal of Southwest Forestry University 6: 25-30.

[21] Mao, Y. T., Wang, C., Sun, C. H., Chen, X. Y., Li, Y. Z., Wen, X. J. (2017): Study on resistance of Aquilaria sinensis against Heortia vitessoides. - Journal of South China Agricultural University 38(6): 89-96. 
[22] Mo, H. Z., Zhang, X. Y., Huang, C. T., Xu, R. J., Zhou, X. G., Wei, Y. N., Tang, X. Q. (2011): Conservation and utilization of the floristic diversity of Xijing village Fengshui Wood in Zengcheng City. - Guangdong Agricultural Sciences 24: 144-148.

[23] Peng, S. L. (1996): Dynamics of Plant Communities in the Subtropical. - Science Press, Beijing.

[24] Ren, H., Peng, S. L., Zhang, Z. P., Zhang, W. Q. (1996): Study on canopy structure and canopy radiation of monsoon evergreen broad leaf forest in Dinghushan Biosphere Reserve, Guangdong. - Acta Ecologica Sinica 16(2): 174-179.

[25] Ren, H., Peng, S. L., Liu, H. X., Yu, Z. Y., Fang, D. Y. (1998): Litter fall and its ecological effects at Xiaoliang tropical artificial mixed plantation. - Chinese Journal of Applied Ecology 9(5): 458-462.

[26] Song, Y. C., Chen, X. Y., Wang, X. H. (2005): Studies on evergreen broad-leaved forests of China: a retrospect and prospect. - Journal of East China Normal University (Natural Science) 1: 1-8.

[27] Tang, G. D., Chen, D. P., Luo, S. Q., Zheng, M. X., Hou, B. Q., Xu, Z. C. (2012): Plant community diversity of geomantic woods in Jiangpu, Conghua, Guangzhou, Guangdong. - Guangdong Forestry Technology 28(1): 1-6.

[28] Wang, R., He, Q., Ding, X. G., Li, J. Y., Zhang, F. Q., Pan, W. (2012): Analysis on soil characters of the growing environment and nutrition characteristic of Aquilaria sinensis. Ecology and Environmental Sciences 21(4): 666-672.

[29] Yang, Q. H., Chen, M. F., Lai, W. N., Yang, H. S., Kuang, W. (2012): Community characteristics investigation of Fengshui Woods in Eastern Guangdong Province. Journal of Southern Agriculture 43(12): 2040-2044.

[30] Ye, H. G., Xu, Z. C., Wu, M., Cao, H. L. (2013): Guangzhou Fengshui Forest. Huazhong University of Science and Technology University Press. Wuhan.

[31] Yi, Q. F., Wang, F. G., Liu, D. M., Chen, H. F., Xing, F. W. (2012): Analyses on species composition and community structure of "Fengshui woods" in Luogang District in Guangzhou City. - Journal of Plant Resources and Environment 21(1): 104-110.

[32] Zhu, B. Z., Zhang, F. Q., Li, Z. K., Wang, R., Pan, W., Wang, Y. X. (2011): The community characteristics and conservation of geomantic forest including Aquilaria sinensis in Guangzhou. - Guangdong Forestry Technology 27(2): 15-21. 